\title{
COMMUNITY VIEWS ON EDUCATION IN INDONESIA
}

BY

GEORGE CLOONEY

2019 


\section{KATA PENGANTAR}

Puji syukur kami panjatkan Kepada allah SWT atas anugrah-Nya sehingga kami dapat menyelesaikan penulisan makalah tentang Pancasila Sebagai Ideologi.

Adapun maksud dan tujuan dari penyusunan Makalah ini selain untuk menyelesaikan tugas yang diberikan oleh Dosen pengajar, juga untuk lebih memperluas pengetahuan para mahasiswa khususnya bagi penulis.

Penulis telah berusaha untuk dapat menyusun Makalah ini dengan baik, namun penulis pun menyadari bahwa kami memiliki akan adanya keterbatasan kami sebagai manusia biasa.

Oleh karena itu jika didapati adanya kesalahan-kesalahan baik dari segi teknik penulisan, maupun dari isi, maka kami memohon maaf dan kritik serta saran dari dosen pengajar bahkan semua pembaca sangat diharapkan oleh kami untuk dapat menyempurnakan makalah ini terlebih juga dalam pengetahuan kita bersama. 


\section{DAFTAR ISI}

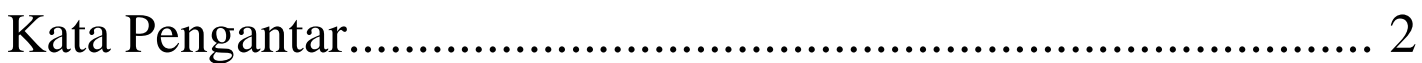

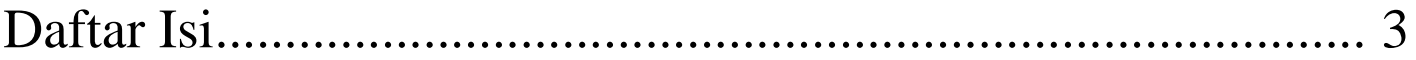

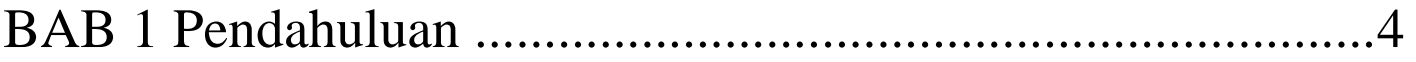

1. Latar Belakang.................................................................. 4

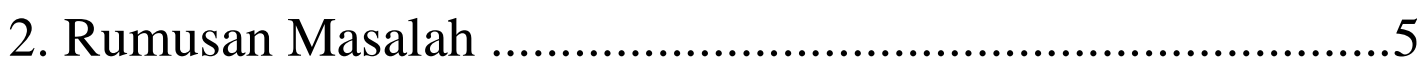

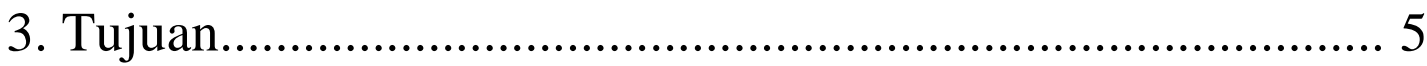

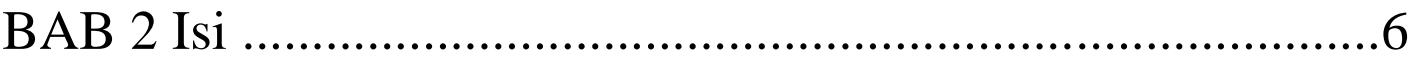

1. Karakteristik dan Makna Ideologi bagi Negara..................... 7

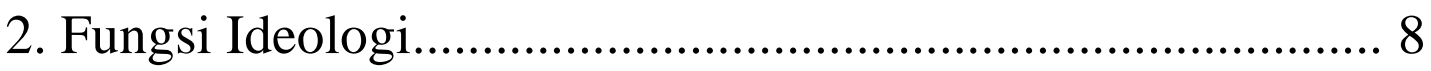

3. Pancasila sebagai Ideologi Terbuka …………………...........9

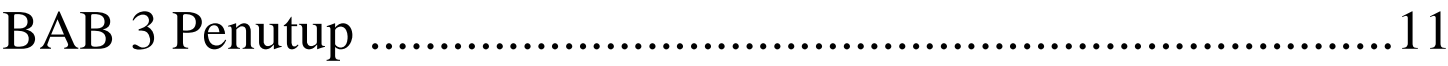

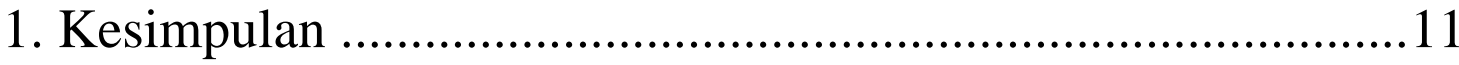

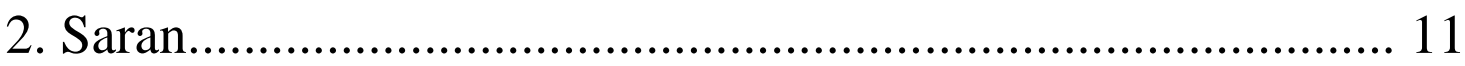

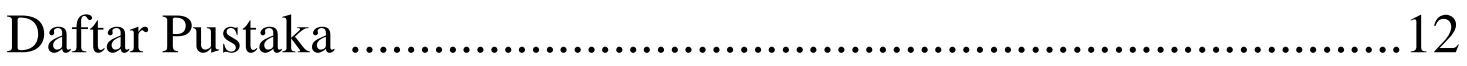




\section{BAB I \\ PENDAHULUAN}

\section{Latar Belakang}

Setiap bangsa dan negara yang ingin berdiri kokoh kuat, tidak mudah terombangambing oleh kerasnya persoalan hidup berbangsa dan bernegara, sudah barang tentu perlu memiliki dasar negara dan ideologi negara yang kokoh dan kuat pula. Tanpa itu, maka bangsa dan negara akan rapuh.

Mempelajari Pancasila lebih dalam menjadikan kita sadar sebagai bangsa Indonesia yang memiliki jati diri dan harus diwujudkan dalam pergaulan hidup sehari-hari untuk menunjukkan identitas bangsa yang lebih bermartabat dan berbudaya tinggi. Sejarah Lahirnya Pancasila sebagai Ideologi dan Dasar Negara Ideologi dan dasar negara kita adalah Pancasila. Pancasila terdiri dari lima sila. Kelima sila itu adalah: Ketuhanan yang Maha Esa, Kemanusiaan yang adil dan beradab, Persatuan Indonesia, Kerakyatan yang dipimpin oleh hikmat kebijaksanaan dalam permusayawaratan perwakilan, dan Keadilan sosial bagi seluruh rakyat Indonesia.

Sebelum tanggal 17 Agustus bangsa Indonesia belum merdeka. Bangsa Indonesia dijajah oleh bangsa lain. Banyak bangsa-bangsa lain yang menjajah atau berkuasa di Indonesia, misalnya bangsa Belanda, Portugis, Inggris, dan Jepang. Paling lama menjajah adalah bangsa Belanda. Padahal sebelum kedatangan penjajah bangsa asing tersebut, di wilayah negara RI terdapat kerajaan-kerajaan besar yang merdeka, misalnya Sriwijaya, Majapahit, Demak, Mataram, Ternate, dan Tidore.

\section{Rumusan Masalah}

- Apa arti dari pancasila sebagai ideologi negara?

- Apa makna ideologi bagi Negara?

- Apa fungsi ideologi bagi Negara?

- Apa maksud dari Pancasila sebagai Ideologi terbuka?

\section{Tujuan}

1. Dapat menjelaskan Pancasila sebagai dasar negara dan ideologi negara.

2 .Dapat menguraikan nilai-nilai Pancasila sebagai dasar negara dan ideologi negara.

3. Dapat menunjukan sikap positif terhadap pancasila dalam kehidupan berbangsa dan bernegara.

4. Menampilkan sikap positif terhadap Pancasila dalam kehidupan bermasyarakat. 


\section{BAB II}

\section{ISI}

Istilah ideologi berasal dari kata idea dan logos. Idea yang berarti gagasan, konsep, pengertian dasar, ide-ide dasar,cita-cita. Kata idea berasal dari bahaa Yunani, eidos yang berarti bentuk atau idein yang berarti melihat. Idea dapat diartikan sebagai cita-cita, yaitu cita-cita yang bersifat tetap dan akan dicapai dalam kehidupan nyata.

Dengan demikian, cita-cita ini pada hakikatnya merupakan dasar, pandangan atau faham yang diyakini kebenarannya. Sedangkan logos berarti ilmu. Secara harfiah,ideologi berarti ilmu pengetahuan tentang ide-ide atau ajaran tentang pengerian dasar. Pokok-pokok pikiran yang perlu dikemukakan mengenai ideologi adalah sebagai berikut :

1. Pokok ideologi merupakan sistem pemikiran yang erat kaitannya dengan perilaku manusia. Kecuali itu, ideologi merupakan serangkaian pemikiran yang berkaitan dengan tertib sosial dan politik yang ada dan berupaya untuk merubah atau mempertahankan tertib sosial dan politik yang bersangkutan.

2. Bahwa ideologi, disamping mengemukakan program juga menyertakan strategi guna merealisasikannya.

3. Bahwa ideologi dapat dipandang sebagai serangkaian pemikiran yang dapat mempersatukan manusia, kelompok atau masyarakat yang selanjutnya diarahkan pada terwujudnya partisipasi secara efektif dalam kehidupan sosial politik.

Bahwa yang bisa merubah suatu pemikiran menjadi ideologi adalah fungsi pemikiran menjadi ideologi adalah fungsi pemikiran itu dalam berbagai lembaga

\section{A. Karakterstik dan Makna Ideologi bagi Negara}

Dalam memahami ideologi dan ideologi politik tidaklah cukup hanya dengan melihat dari sosok pengertiannya, atau hanya berangkat dari definisi-definisi yang telah dikemukakan para ahli. Makna Ideologi dapat ditemukan dari karakteristiknya. Beberapa karakteristik suatu ideologi, antara lain :

1. Ideologi sering muncul dan berkembang dalam situasi krisis

Situasi krisis dimana cara pandang, cara berpikir dan cara berindak yang sebelumnya dianggap umum dan wajar dalam suatu masyarakat telah dianggap sebagai suatu yang sudah tidak bisa diterima lagi.Keadaan seperti ini biasanya akan mendorong muncul munculnya suatu ideologi. 
2. Ideologi merupakan pola pemikiran yang sistematis

Ideologi pada dasarnya merupakan ide atau gagasan yang dilemparkan atau ditawarkan ketengahtengah arena perpolitikan. Oleh karena itu, ideologi harus disusun secara sistematis agar dapat diterima oleh warga masyarakat secara rasional.

3. Ideologi mempunyai ruang lingkup jangkauan yang luas, namun beragam

Dilihat dari dimensi horisontal, ideologi mempunyai ruang lingkup yang sangat luas, mulai dari penjelasan-penjelasan yang parsial sifatnya sampai kepada gagasan-gagasan atau pandanganpandangan komprehensif.

4. Ideologi mencangkup beberapa strata pemikiran dan panutan

Dilihat dari dimensi vertikal, ideologi mencangkup beberapa strata pemikiran dan panutan, mulai dari konsep yang kompleks dan shophisticated sampai dengan slogan-slogan atau simbol-simbol sederhana yang mengekspresikan gagasan-gagasan tertentu sesuai dengan tingkat pemahaman dan perkembangan masyarakat.

\section{B. Fungsi Ideologi}

Tumbuhnya keyakinan da kepercayaan terhadap ideologi tertentu, barangkali bukan satu-satunya cara, melalui mana manusia bisa memformulasikan dan mengisi kehidupannya. Ideologi juga mempermainkan fungsinya dalam mengatur hubungan antara manusia dan masyarakat.setiap kehidupan masyarakat pasti mengharapkan setiap anggotanya dapat terlibat didalamnya. Untuk itu ideologi dapat membantu anggota masyarakat dalam upaya melibatkan diri dalam berbagai sektor kehidupan. Dsamping fungsinya yang sangat umum,ideologi juga memiliki fungsi khusus sifatnya, antara lain :

1. Ideologi berfungsi melengkapi struktur kognitif manusia

Sebagai sistem panutan, ideologi pada dasarnya merupakan formulasi ide atau gagasan melalui ana manusia dapat menerima, memahami, dan sekaligus menginteptasikan hakikat kehidupan ini.

2. Ideologi berfungsi sebagai panduan.

Sebagai suatu panduan, ideologi mencanangkan seperangkat patokan tentang bagaimana manusia seharusnya bertingkah laku, disamping tujuan dan cara mencapai tujuan itu.

3. Ideologi berfungsi sebagai lensa

Ideologi merupakan salah satu alat bagi seseorang atau bangsa untuk mengenal dan melihat dirinya sendiri dan mengharapkan orang lain untuk bisa melihat dan mengitepretasikan tindakannya yang didasarkan atas ideologinya.

4. Ideologi berfungsi sebagai kekuatan pengendali konflik.

Dalam level personal, ideologi dapat membantu setiap individu dalam mengatasi konflik yang terjadi dalam dirinya ataupun dalam hubungan dengan orang lain. Dalam kehidupan masyarakat, ideologi juga dapat berfungsi membatasi konflik.

\section{Pancasila sebagai Ideologi Terbuka}

Pancasila sebagai ideologi bangsa Ideologi bangsa Indonesia mengandung nilai-nilai dan gagasan-gagasan dasar yang dapat dilihat dalam sikap, perilaku, dan kepribadian bangsa Indonesia.

Menurut Alfian, suatu ideologi yang baik harus mengandung tiga dimensi agar supaya dapat memelihara relevansinya yang tinggi/kuat terhadap perkrmbangan aspirasi masyarakat dan 
tuntutan perubahan zaman. Kehadiran ketiga dimensi yang saling berkaitan, saling mengisi, dan saling memperkuat itu menjadikan ideologi yang kenyal dan tahan uji dari masa ke masa.

Dimensi-dimensi sebagai mana tersebut di atas dapat dijelaskan secara rinci sebagai berikut: a.Dimensi Realitas

Ideologi merupakan nilai-nilai dasar yang bersumber dari nilai-nilai yang hidup di dalam masyarakatnya, terutama pada waktu ideologi itu lahir. Dengan demikian, masyarakat pendukung ideologi itu dapat merasakan dan menghayati bahwa nilai-nilai dasar itu milik merekabersama.

\section{b.Dimensi Idealitas}

Ideologi ini mengandung cita-cita yang ingin dicapai dalam berbagai bidang kehidupan bermasyarakat, bebangsa, dan bernegara. Dengan demikian, bangsa yang memiliki ideologi adalah adalah bangsa yang telah mengetahui kearah mana mereka akan membangun bangsa dan negaranya.

\section{c.Dimensi Fleksibilitas}

Ideologi harus memberikan ruang yang memungkinkan berkembangnya pemikiran-pemikiran baru tentang ideologi tersebut, tanpa menghilangkan hakikat yang terkandung didalamnya. Ideologi terbuka adalah ideologi yang dapat berinteraksi dengan perkembangan zaman, dan dinamika internal. Dinamika internal tersebut memberi peluang kepada penganutnya untuk mengembangkan pemikiran-pemikiran baru yang relevan dan sesuai dengan perkembangan dari masa ke masa. Dengan demikian,ideologi tersebut tetap aktual,selalu berkembang dan menyesuaikan diri dengan perkembangan masyarakat. 


\section{BAB III \\ PENUTUP}

\section{Kesimpulan:}

Pancailai sebagai dasar negara dan pandangan hidup sekaligus juga merupakan ideologi negara. Sebagai ideologi negara berarti pancasila merupakan gagasan dasar yang berkenaan dengan kehidupan negara.Pancasila bukan hanya suatu yang bersifat statis melandasi berdirinya negara Indonesia akan tetapi pancasila membawakan gambaran mengenai wujud masyarakat tertentu yang diinginkan serta prinsip-prinsip dasar yang harus diperjuangkan untuk mewujudkannya. Pancasila membawakan nilai-nilai tertentu yang digali dari realitas sodio budaya bangsa Indonesia. Ideologi membawakan kekhasan tertentu yang membedakannya dengan ideologi lainnya. Kehasan itu adalah keyakinan akan adanya Tuhan Yang Maha Esa,yang membawa konsekuensi keimanan dan ketaqwaan terhadap Tuhan Yang Maha Esa. Keberadaan ideologi Pancasila dilihat dari dimensi realitas membawakan nilai-nilai yang mencerminkan realitas sosiobudaya bangsa Indonesia, dari segi idealitas mamidpu memberikan keyakian akan terwujudnya masyarakat yang dicita-citakan, dan dari dimensi Fleksibilitas, nilai-nilai yang ada didalamnya dapat dijabarkan secara konstektual agar senantiasa dapat menyesuaikan dengan dinamika dan perkembangan masyarakat.

\section{Saran:}

Sebagai rakyat Indonesia kita sebaiknya selalu menjaga ideologi negara kita yaitu Pancasila karena pancasila merupakan gagasan dasar yang berkenaan dengan kehidupan negara. 


\section{NAMA : IBU UPIK \\ PEKERJAAN : PENGUSAHA \\ USIA : 46 TAHUN}

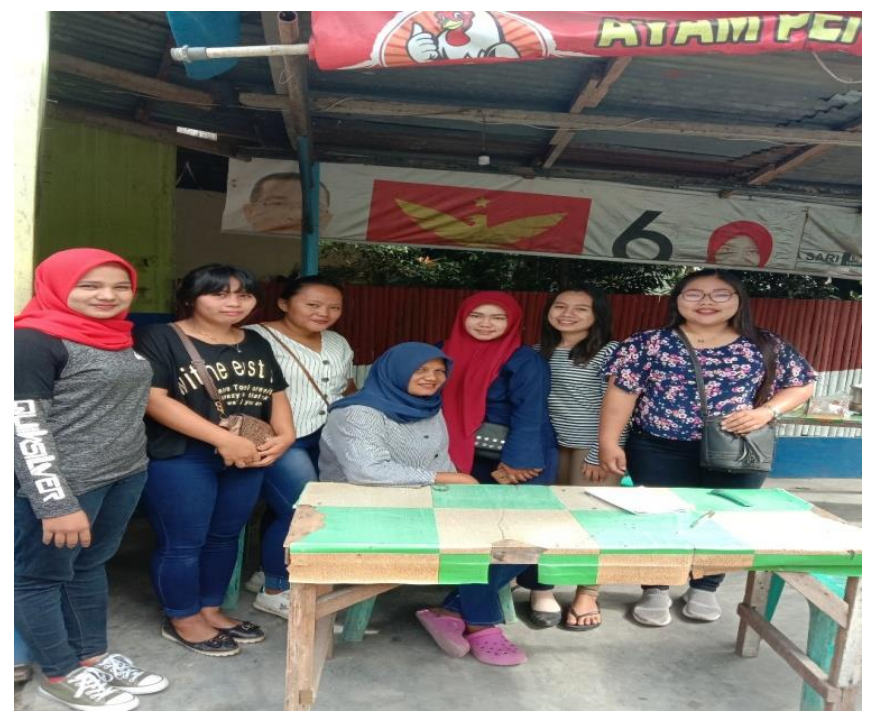

Tepatnya pada tanggal 09 November 2019 kami melaksanakan wawancara ke suatu tempat yang beralamat Jln. Tanjung Sari. Kami menggunjungi seorang ibu penjual lontong dan meminta waktunya untuk diwawancarai. Ibu itu pun dengan tertawa, kalian kasih ibuk apa guraunya,,. Kami pun menjawab nya upah mu besar disurga,wkwkkwkk,lalu ibu itu pun menjawab becandanya, karna anak ibuk juga pernah melaksanakan wawancara dari tugas kampusnya. Lalu ibuk itu pun bersedia dan kami pun mulai mengajukan pertanyaan kepadanya. Tentang, Bagaimana pandangan ibu terhadap ideologi Pancasila?

Menurut saya Pancasila sebagai ideologi negara yang menjadi pedoman hidup bagi seluh rakyat Indonesia yang memang berasal dari nilai-nilai luhur budaya dan religious bangsa Indonesia. Ideologi Pancasila bersifat terbuka artinya ideology Pancasila dapat berkontribusi dengan kemajuan zaman dengan tetap berlandaskan ideologi Pancasila atau nilai-nilai Pancasila.

Karena ideologi Pancasila mengandung nilai instrumental, nilai dasar dan nilai praktis. Pancasila lahir dan diangkat dari nilai-nilai adat istiadat dan kebudayaan serta religious yang terdapat dalam pandangan -pandangan hidup Indonesia sebelum membentuk sebuah negara Indonesia atau sebelum lahir nya negara Indonesia. Kami pun mengucapkan terima kasih banyak kepada ibu upik dan bersalaman kepadanya. 


\section{NAMA:NAZAR UDIN \\ USIA :46 Tahun \\ Pekerjan :Depot}

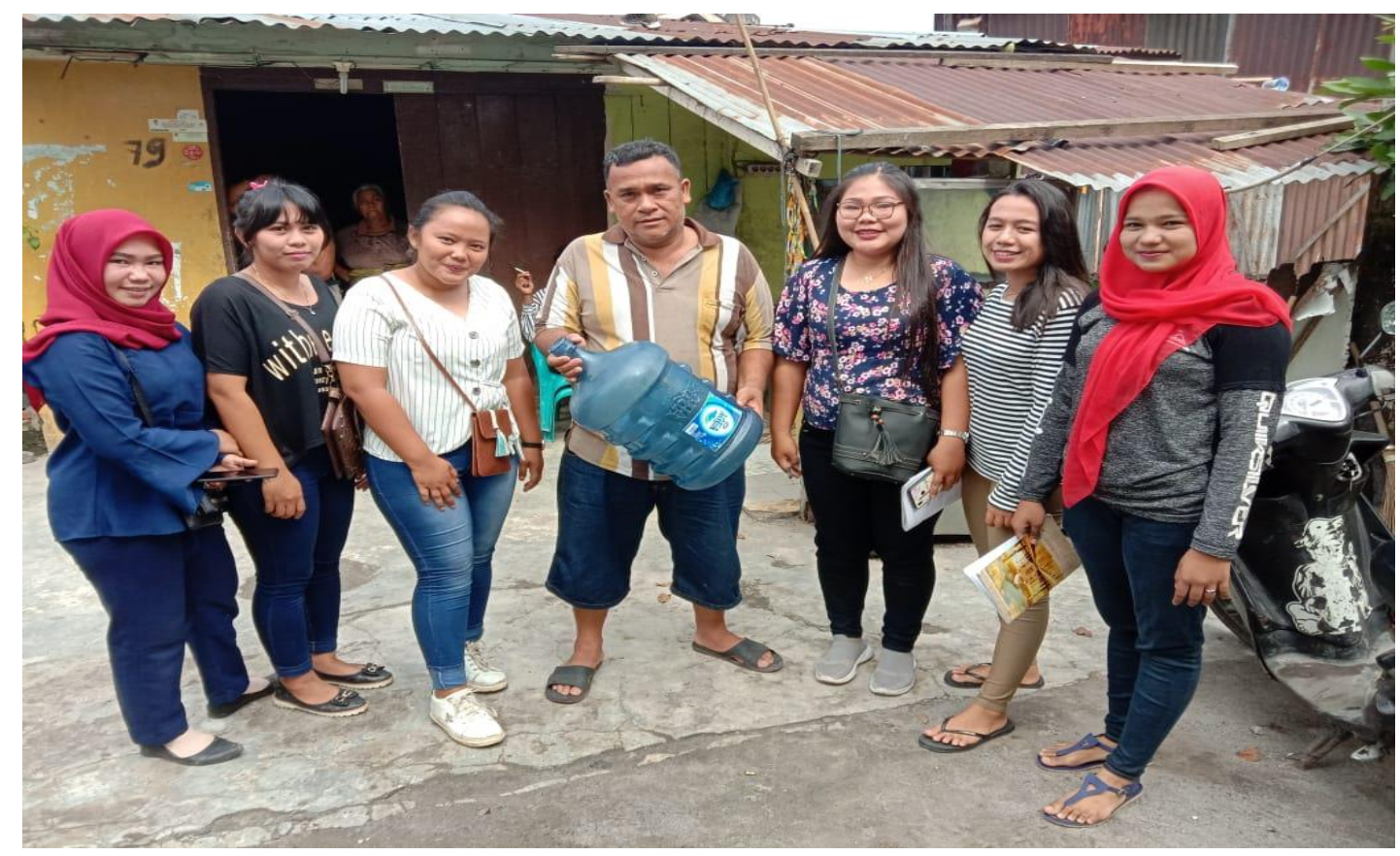

Tepatnya pada tanggal 09 November 2019 kami pun melanjutkan wawancara kedua kami kepada bapak Nazar Udin. Kami pun menjumpai dia yang mau bergegas mengantar kan orderan galon airnya. Namun dia bersedia untuk diwawancarai dan diminta waktunya. Selamat siang pak kami dari kampus universitas quality ingin meminta waktu bapak sebentar untuk kami wawancari. Bapak Nazar pun bersedia, silahkan emangnya ini tugas apa ya dk,,. Ini tugas dari kampus tentang ideologi pancasila. Oooo, ya sudah silahkan, kami pun langsung mengajukan pertanyaannya kepada nya. Tentang bagaimana pendapatnya penting nya ideologi negara tersebut di negara indonesia.

Menurut bapak seberapa penting ideologi bagi negara kita?

Menurut saya sangat lah penting karena menjadi tolak ukur pedoman dan panduan hidup dalam menjalani kehidupan berbangsa dan bernegara .Sehingga intergerasi bangsa dapat dijaga dan disintegerasi bangsa dihindari.

a. Memberikan arah yang mantap dalam berkelompok dan menggerakkannya menuju tujuan masyarakatnya.

b. Untuk membentuk identitas kelompok atau bangsa dan mempersatukannya dalam satu kesatuan yang utuh. 
c. Untuk mengatasi berbagai komplik dan ketegangan sosial yang menjadi serta menjadikannya sebagai kehidupan yang penuh solidaritas dan kebersamaan.

d. Untuk mempersatukan berbagai keanekaragaman yang ada dalam kehidupan berbangsa dan bernegara.

Bapak ini juga mengerti dan tau betapa pentingnya ideologi pancasila terhadap negara kita ini. Jadi kami pun ingin bergegas dan mengucapkan terima kasih kepada bapak tersebut. Ya sama-sama semoga kalian nantinya menjadi guru yang berprestasi ya nak, kami pun menjawabnya dengan semangatttt, Aminnn. 


\section{NAMA : SUPIA \\ PEKERJAAN : LAUNDRY \\ USIA : 27 TAHUN}

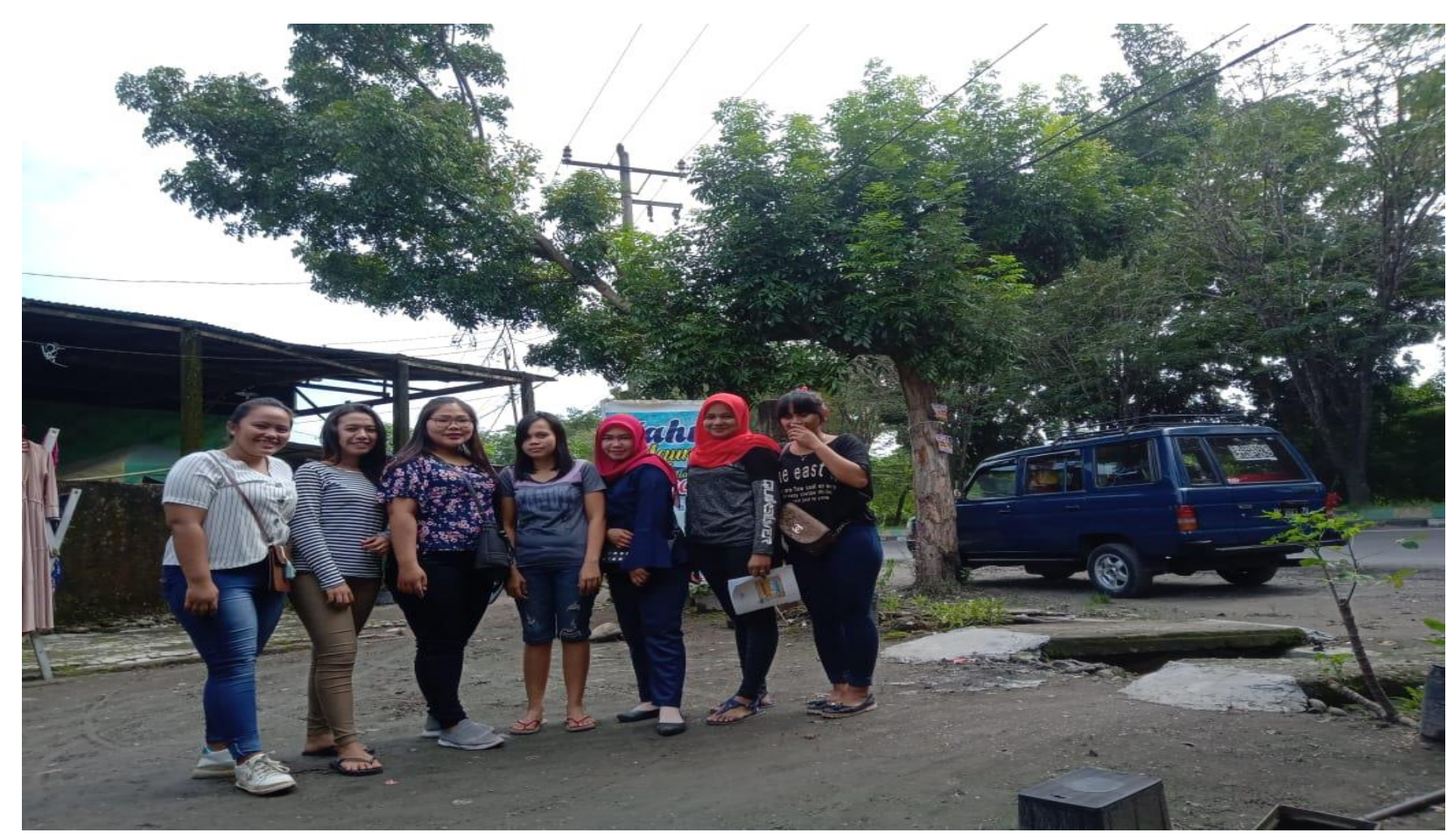

Tepatnya pada tanggal 09 November 2019 kami pun melanjutkan wawancara ketiga kami kepada ibu Supia seorang pemilik laudry. Yang berusia 27, kami meminta waktu nya untuk kami wawancarai, ternyata ibu tersebut lagi sibuk dengan pakain orderan pelanggannya ibu itu pun meminta tolong kami agar bersabar menunggu dia. Kami pun menunggunya, lalu ibu supia pun langsung keluar dan bersedia untuk kami wawancarai.

Emang nya kalian mau wawancara tentang apa ya dk? Tanya ibuk supia kepada kami kami pun menjawa, bahwa ini tugas dari kampus buk, lalu ibuk itu pun menjawab baik lah ibuk bersedia. Kami pun langsung mengajukan pertanyaan kami kepada ibu supia tersebut. Bagaimana pandangan ibu jika ideologi Pancasila diganti menjadi ideologi lain?Menurut saya tidak usah diubah karena sudah pas dengan kepribadian bangsa Indonesia.Apabila ideologi Pancasila diganti dengan ideologi lain otomatis keperibadian dan tata aturan masyarakat ikut berubah, karena Pancasila selain nilai dasar negara merupakan pandangan hidup bangsa Indonesia yang menjadi petunjuk dalam kehidupan sehari-hari. Masyarakat Indonesia baik dari segi sikap maupun prilaku harus dijiwai oleh nilai-nilai Pancasila. Ibu supia pun mulai paham dengan pertanyaan yang kami ajukan kepadanya. Kami pun langsung mengakhiri wawancara kami dengan mengucapkan terimakasih banyak kepada ibuk supia sudah meluangkanwaktu untuk kami wawancarai. 


\section{NAMA : MUHAMMAD ARIF \\ PEKERJAAN : PEDAGANG \\ USIIA : 26 TAHUN}

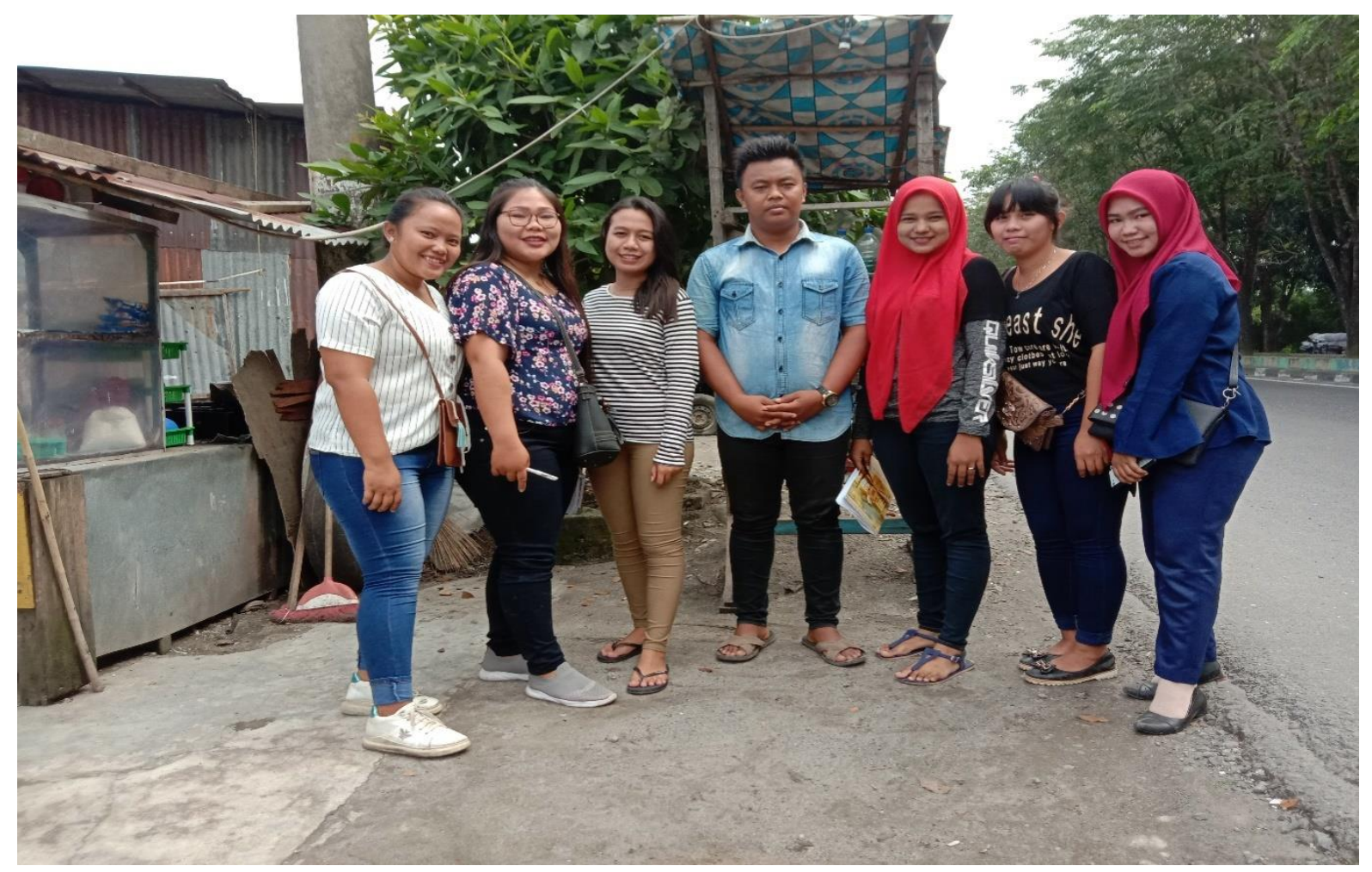

Tepatnya pada tanggal 09 November 2019 kami pun langsung lenjutkan wawancara keempat kami, kami pun menjumpai seorang pedagang kaki lima, yang sedang duduk santai menunggu pembelinya. Kami pun menjumpainya, selamat siang bg apakah kami bisa meminta sedikit waktunya untuk kami wawancari sebentar. Emangnya mau wawancara tentang apa ya $\mathrm{dk}$, ,? Tentang ideologi pancasila bg ini tugas dari kampus yang akan kami tanyakan kepada abg. Baiklah silahkan saja, kami pun langsung memanfaatkan waktu ini untuk menayakan abg tersebut dan mengajukan pertanyaan tersebut kepadanya. Apa tujuan bangsa memiliki ideologi Pancasila? Menurut saya sebagai mempersatu bangsa Indonesia.

a. Menyatukan bangsa Indonesia, memperkokoh dan memelihara kesatuan dan persatuan.

b. Membimbing dan mengarahkan bangsa Indonesia untuk mencapai tujuannya.

c. Memberikan kemauan untuk memelihara dan mengembangkan identitas bangsa Indonesia.

d. Menerangi dan mengawasi keadaan serta kritis kepada adanya upaya untuk mewujudkan cita-cita yang terkandung di dalam Pancasila.

e. Sebagai pedoman bagi kehidupan bangsa Indonesia dalam upaya menjaga keutuhan negara dan memperbaiki kehidupan dari bangsa Indonesia. 
Karna itu lah masyarakat indonesia harus tetap menjaga persatuan tanah air dan selalu menjunjung tinggi tanah air kita Indonesia. Baik lah menurut saya abg ini sudah mulai mengerti betapa pentinggnya memelihara kesatuan republik indonesia. Kami pun mengakhiri wawancara kami dan mengucapkan terima kasih kepadanya sudah menyempatkan waktunya untuk kami wawancarai. 


\section{NAMA : HASIM \\ PEKERJAAN : SUPIR ANGKOT \\ USIA : 35 TAHUN}

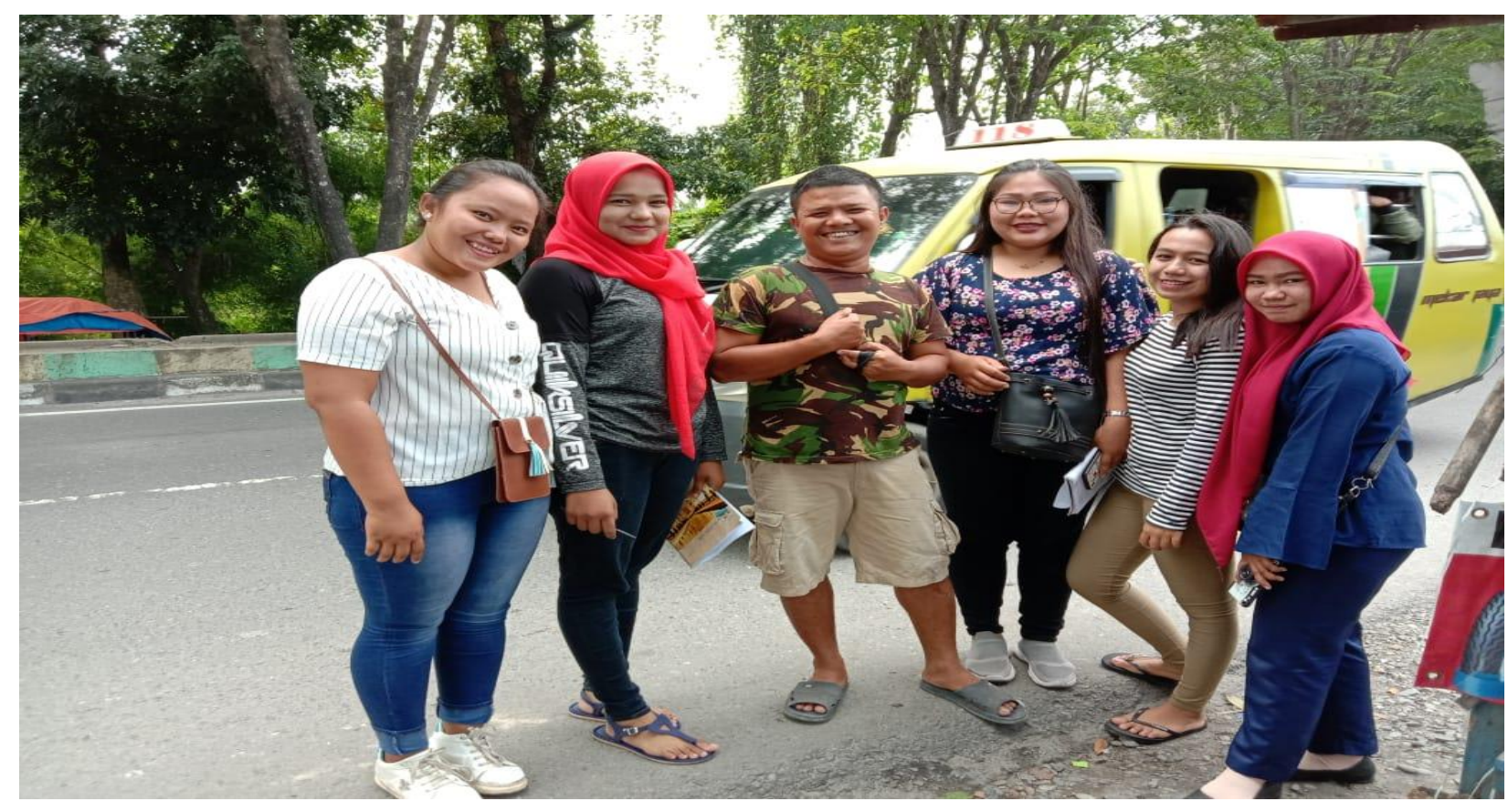

Tepatnya pada tanggal 09 November 2019 kami pun melanjutkan kembali wawancara kami sambil berkeliling untuk mencari warga yang bisa kami wawancari. Kami pun berjumpa bersama supir angkot yang sedang membeli rokok, dan kami pun meminta waktu nya untuk kami wawancarai. Selamat siang pak, apa kah bapak bersedia untuk kami wawancari, emangnya ini tugas apa ya kalau boleh tau nak, Nanti bapak kalian jual gurau bapak tersebut,wkwk. Ya sudah lah apa yang mau kalian tanyakan kepada bapak.

Baik kami pun langsung mengajukan pertanyaan kami kepada bapak tersebut. Mengapa Pancasila dipilih sebagai dasar negara Indonesia?Menurut saya Pancasila sebagai ideologi negara sangat cocok untuk menjadi dasar negara dan sesuai dengan kepribadian bangsa Indonesia yang sejak dulu menganut adat ketimuran bermacam-macam budaya dan suku daerah nya. Yang meskipun sekarang sudah mulai tergeser dengan budaya bebas barat. Yang warga negara nya walaupun beraneka ragam tetapi tetap bersatu dan menjunjung tinggi tanah air indonesia. Pancasila merupakan suatu simbol yang kas bangsa indonesia ini.

Baik bapak ini pun mulai terburu-buru untuk melanjutkan pekerjaanya kami pun mengakhiri wawancara kami dengan mengucapkan terima kasih kepada bapak terdebut. 


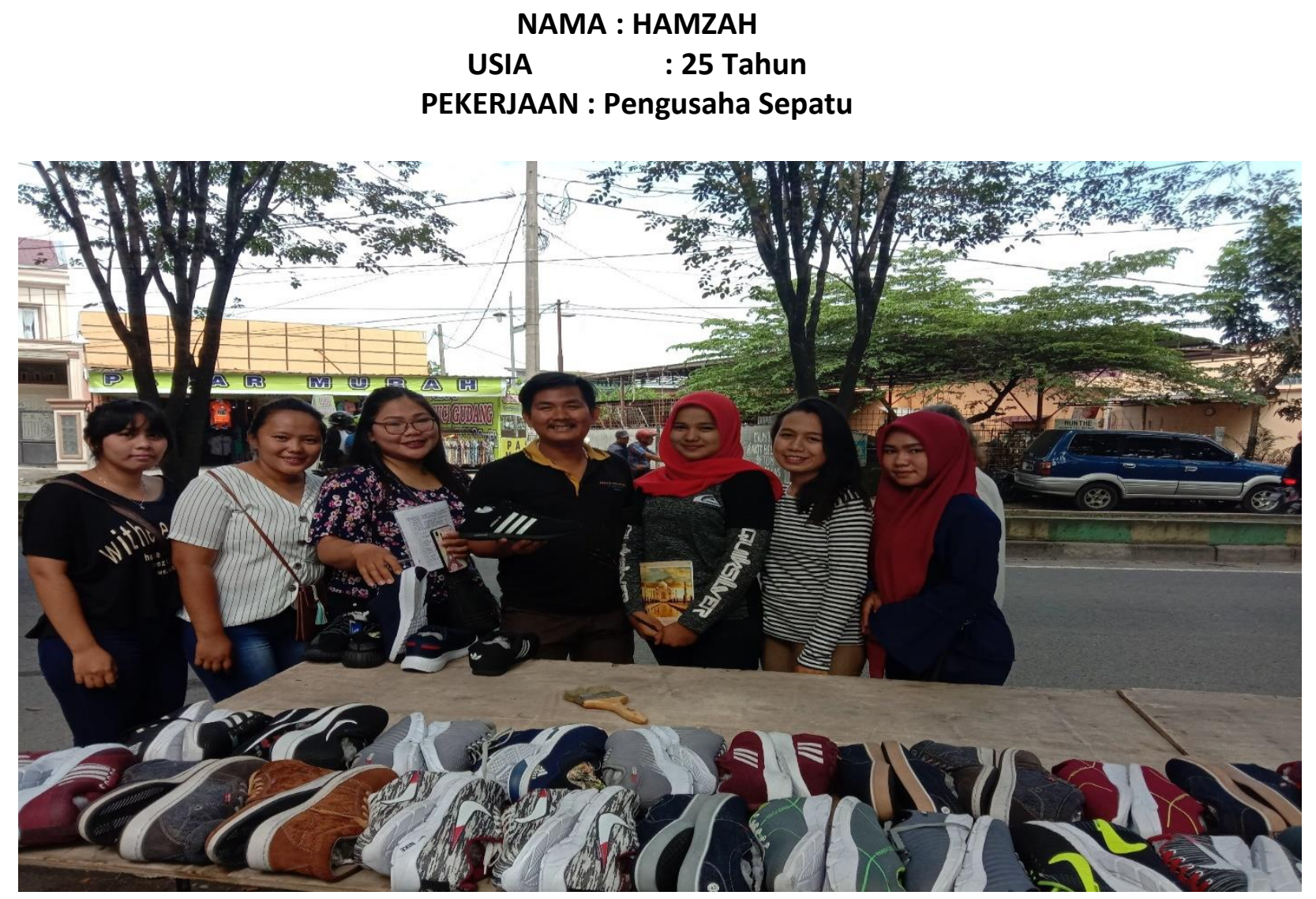

Tepatnya pada tanggal 09 November 2019 kami pun melanjutkan wawancara yang keenam kepada seorang pengusaha sepatu yang bernama Hamzah iya berusia 25 tahun. Kami pun menghampirinya selamat siang bang, siang eee kok rame ya,, dk pada mau beli sepatu sama abg ya,, gurau abang tersebut ,,kami tertawa dengan pertanyaannya. Tidak bg kami mau meminta waktu abg untuk kami wawancarai, emangnya tentang apa ya dk? Tentang pancasia sebagai ideologi negara bg, oo coba kalian jelaskan sedikit agar abg bisa menjawab pertanyaanya nanti dengan baik. Kami pun menjelaskan nya bahwa pancasila itu sebagai ideologi adalah lambang atau pedoman hidup benegara. Baik lah saya pun sudah sedikit mengerti apa itu pancasila, Kami pun mengajukan pertanyaan kepada abang tersebut. Tunjukkanlah bukti-bukti rasional yang menyatakan Pancasila adalah nilai dasae fundamental bagi negara Indonesia? mengakui adanya tuhan, menjaga eksetensi negara kesatuan, person yang bernilai, dari oleh dan untuk rakyat

Sosial yaitu ekonomi,politik dan budaya 


\section{NAMA : MADAN \\ USIA :21 Tahun \\ PEKERJAAN : Pengusahan Sepatu}

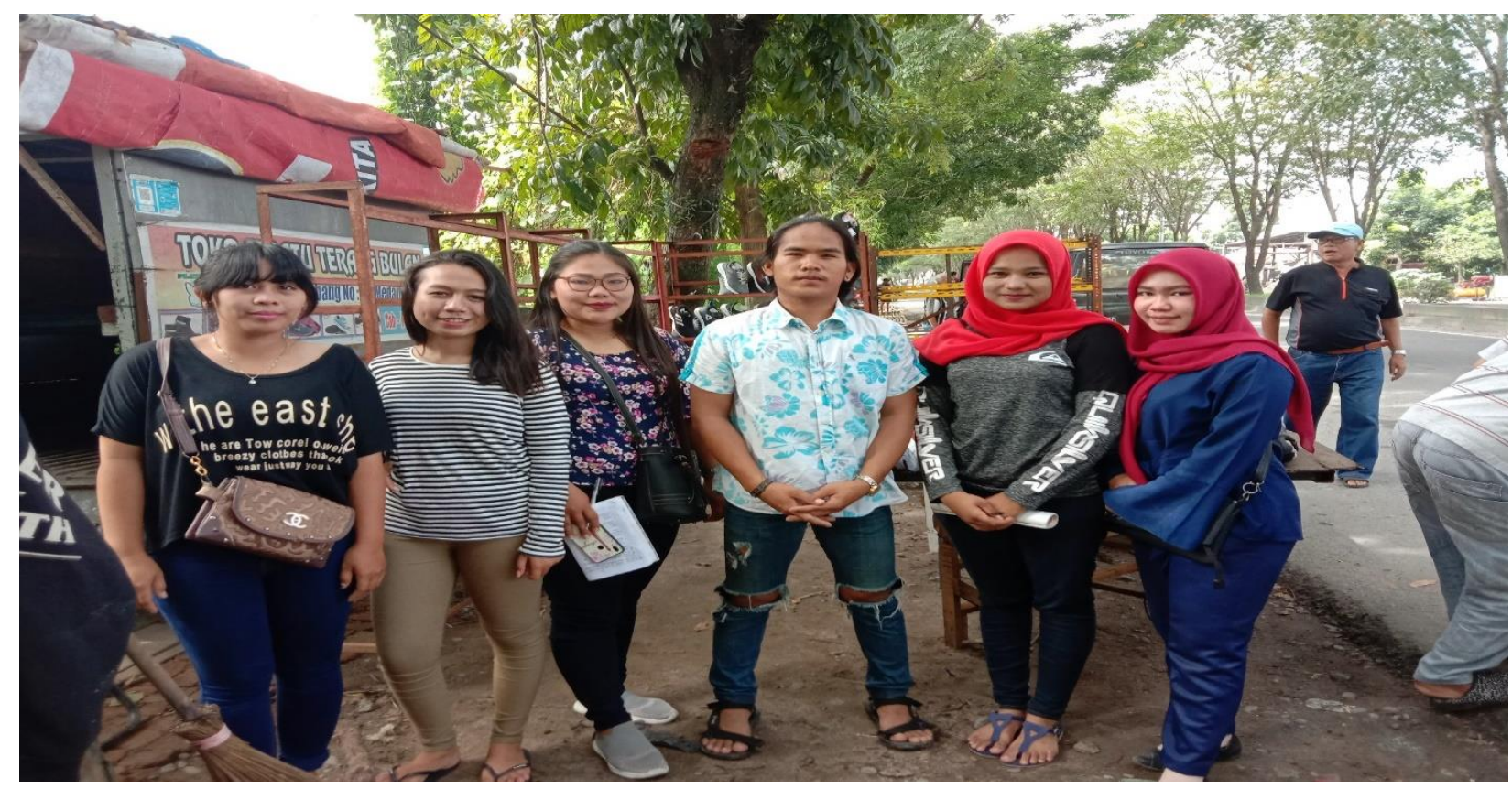

Tepatnya pada tanggal 09 November 2019 kami pun melanutkan wawancara kami yang ketujuh kepada narasumber kami yang ke enam yang bernama Madan usia 21 tahun pekerjaan sebagai pedagang sepatu. Kami pun nenayakan tentang keunggulan pancasila kepadanya diapun langsung bilang waaduhh, bisa dijelaskan terlebih dahulu. Jawabnya, kami pun kmejelaskanny, padahal dia mengerti tetapi dia hanya memainkan kami saja ternyata dia suka becanda. Kami pun langsung menanyakannya nya Sebutkan keunggula-keunggulan yang dimiliki oleh ideologi Pancasila? Ya menurut saya pancasila sangat universal terbuka dan mengikuti peraturan perundang-udangan yang berlaku dan kita bebas mengemukakan hak hita sebagai masyarakat indonesia.

*Pancasila memiliki nilai yang universal

*Sesuai dengan HAM

*Pancasila sebagai ideologi terbuka 


\section{NAMA : RAMES \\ USIA: 45 TAHUN \\ PEKERJAAN: PENGUSAHA}

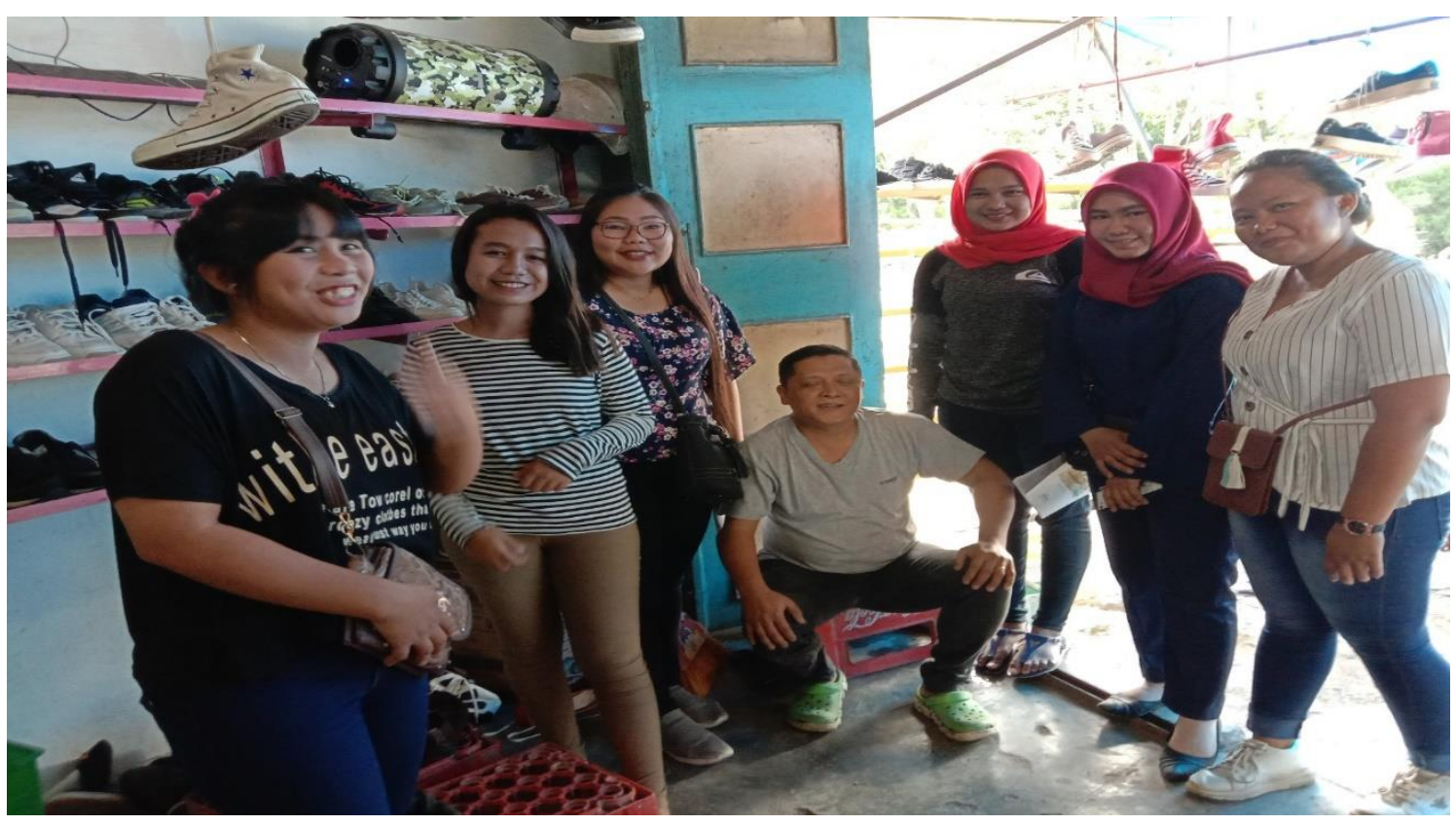

Tepatnya pada tanggal 09 November 2019 kami pun melanjutkan wawancara kami yang ke delapan kami mewawancarai bapak james pemilik toko sepatu yang berusia 45 tahun. Kami pun meminta waktu nya untuk kami wawancarai. Selamat siang pak kami mahasiswa dari universitas quality ingin meminta waktu sebentar untuk bapak agar kami wawancarai sebentar. Y baik lah emang nya ini tugas apaan ya $\mathrm{dk}$,? Tugas pancasila pak yang berjudiul ideologi pancasila. Ooooo, silahkan tetapi cepat ya karna bapak masih banyak urusan lg mau merapikan toko, baiklah pak. Kami pun langsung bergegas mengajukan pertannyaan. Kami pun menayakan, Perbedaan ideologi Pancasila dan ideologi komunisme? Menurut saya pancasila itu sangat baik untuk negara kita karena beraneja ragam budaya, suku, agama, ras, dan sebagainya. Karena pancasila sebagai pedoman hidup masyarakat indonesia dan menjadi mempersatu bangsa indonesoia.

*Ideologi pancasila adalah sebuah ideologi yang memiliki prinsip persatuan dan kebersamaan yang dimiliki manusia dalam kehidupan kebangsaan dan kenegaraan merupakan fungsi pancasilah sebagai ideologi negara.

*Ideologi komunis adalah sebuah ideologi yang bertujuan untuk menghapus semua hak individu dan menggantinya dengan hak-hak umum,yang dikendalikan oleh Negara Republik Indonesia. 


\section{NAMA : DEDI SILALAHI \\ USIA : 40 Tahun \\ PEKERJAAN : Gojek}

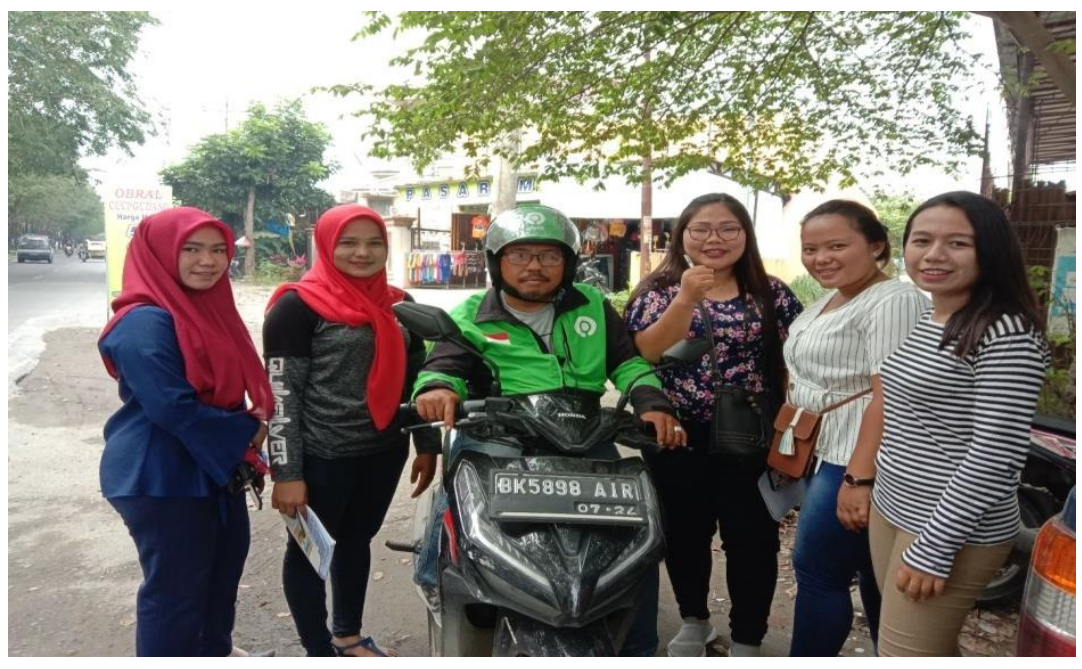

Tepatnya pada tanggal 09 November 2019 kami pun melanjutkan wawancara yang ke drmbilankami, kami pun terus berjalan sambil mencari supir Gojek di pinggir jalan. Kemudian saya pun tak segaja melihat seorang bapak supir gojek tersebut sedang beistirahat di sebuah pohon sambil memainkan hp. Kami pun langsung bergeges menjumpainya dan meminta waktunya. Selamat siang pak, siang dk, ada yang bisa bapak bantu, ya pak kami mahasiswa universitas quality ingin mewawancarai baapak. Apakah bapak bersedia, ya silahkan kami pun langsung mengajukan pertanyaan kami.

Tujuan. Menurut Bapak apa dampak pelanggaran terhadap pancasilah?

Menurut saya pelanggaran Pancasila dapat memperlambat proses terjadinya tujuan, seperti yang diwajibkan penerapan keterampilan,Pancasila untuk mencapai suatu Negara. Dan bagi yang lelanggar peraturan tersebut akan dikenakan sanksi dan barang siapa yang mencela atau menjatuhkan pancasila akan dihukum oleh yang berkewajiban. 


\section{Nama : Siti \\ Umur : 35 tahun \\ Pekerjaan : Ibu rumah tangga}

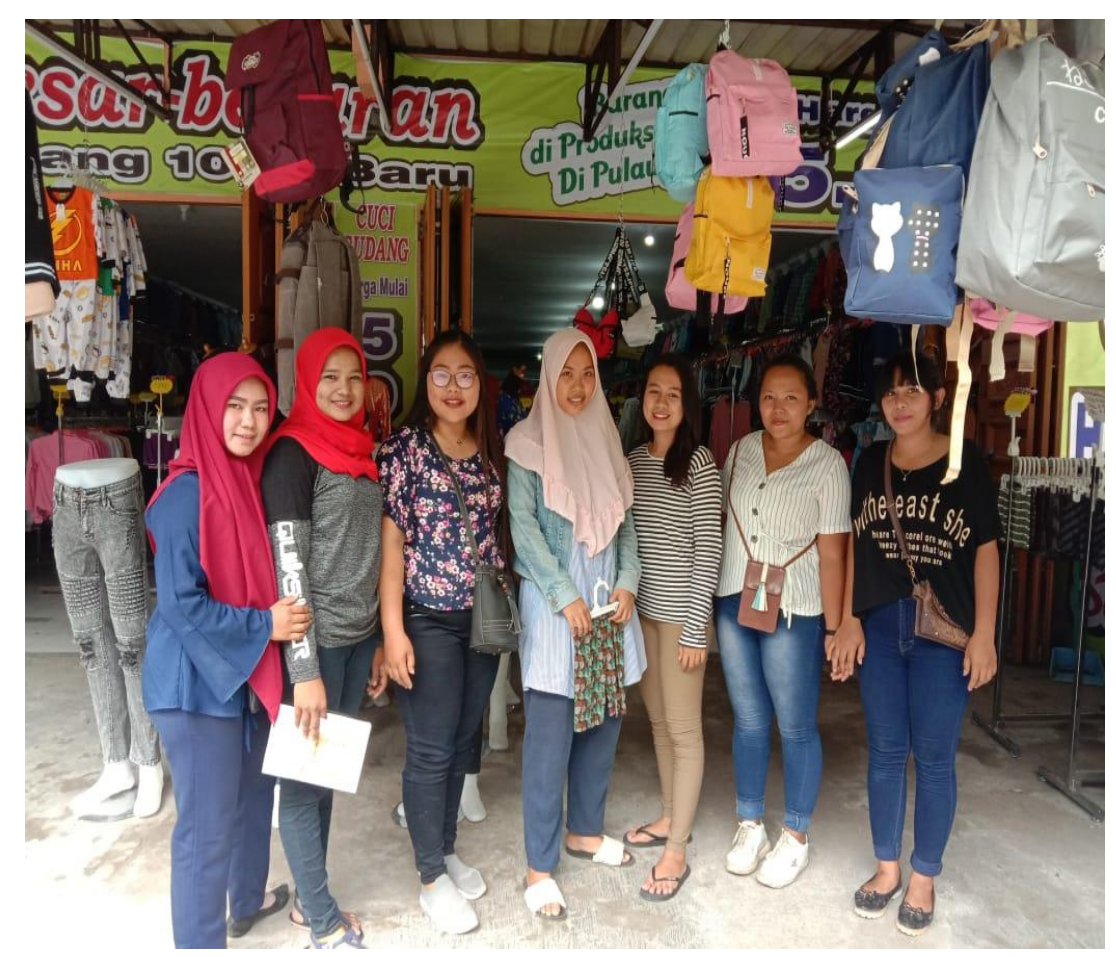

Tepatnya pada tanggal 09 November 2019 ini narasumber kami yang ke sepuluh. Seorang ibu rumah tangga memiliki satu anak. Kami pun meminta waktunya untuk kami wawancarai selamat siang ibu, apak kami bisa meminta waktu ibu sebentar untuk kami wawancarai buk? Ya siang emang nya wawancara apa ya $\mathrm{dk}$, ibuk kurang paham. Baik buk kami mahasiswa dari universitas quality ingin mewawancarai ibuk tentang apa itu pancasila? Ooo, baik lah pancasila itu adalah sebuah lambang negara republik indonesia yang menjadi pemersatu bangsa indonesi yang kita cintai ini. Baiklah buk apakah ibu sudah mampu mengikuti peraturan yang berlaku diindonesia buk? Ya menurut saya sudah karena saya sudah mengikuti sesuai jalur yang diajarkan peraturan perundang-undangan. 


\section{REFERENSI}

https://aseft63.wordpress.com/materi-pelajaran/pkn-kelas-8/pancasila-sebagai-ideologi-dan-dasardasar-negara

Buku paket Pendidikan Pancasila A.T. Soegito, dkk.

Surbakti, K., \& Si, M. (2019). KAJIAN MENGENAI PENTINGNYA BASIS DATA BAGI SEKOLAH SAAT INI. JURNAL CURERE, 2(2).

Surbakti, K. (2018). UPAYA MENINGKATKAN HASIL BELAJAR PKN SISWA DENGAN MENGGUNAKAN MODEL TALKING STICK MATERI SISTEM PEMERINTAHAN PUSAT. JURNAL TEMATIK, 8(1), 166-171.

FRANS. BUDI, PENDIDIKAN YANG MEMERDEKAKAN, GRAMEDIA 2017

JAKOB, H. DASAR-DASAR PENDIDIKAN, PEDAGOG JOURNAL 4(4)

WWW.GOLIATH, EDUCATION FOR CHILD. 4(29). 183-291 